\title{
PENGARUH MODEL PROBLEM BASED LEARNING (PBL) TERHADAP PEMAHAMAN KONSEP DAN KETERAMPILAN BERPIKIR KRITIS SISWA KELAS IV SDN JAMBU HILIR BALUTI 2 PADA MATA PELAJARAN ILMU PENGETAHUAN ALAM
}

\author{
Syahroni Ejin \\ (E-mail: ronikarbol@yahoo.com)
}

\begin{abstract}
Abstrak
Penelitian ini bertujuan melatih kemampuan pemahaman konsep dan kemampuan berpikir kritis siswa kelas IV SDN Jambu Hilir Baluti 2 melalui penggunaan model pembelajaran Problem Based Learning pada materi pencemaran dan etika lingkungan. Pembelajaran ini dirancang agar siswa menemukan sendiri pemecahan masalah melalui tindakan nyata. Jenis penelitian ini merupakan penelitian eksperimen yang membandingkan siswa pada dua kelas yang diberi perlakuan yang berbeda. Rancangan penelitian menggunakan Counter Balanced Design. Subjek penelitian terdiri atas kelas kontrol dan kelas eksperimen. Data penelitian dikumpulkan melalui instrument tes pemahaman konsep berbentuk pilihan ganda dan instrument tes untuk melatih kemampuan berpikir kritis berbentuk esai. Perangkat pembelajaran terdiri dari RPP, Lembar Kegiatan Siswa (LKS), Tes Penguasaan Konsep dan Tes Keterampilan Berpikir Kritis, kemudian di validasi oleh pakar dan setelah dinyatakan valid dan layak, di uji cobakan pada siswa kelas IV SDN Jambu Hilir Baluti 2, pada semester ganjil tahun ajaran 2015/2016. Hasil penelitian menunjukan bahwa validitas perangkat pembelajaran yang dikembangkan layak, keterlaksanaan RPP terlaksana dengan baik, aktivitas siswa mengalami peningkatan berpusat kepada siswa, respon siswa terhadap proses pembelajaran memberikan respon positif, seluruh siswa mencapai ketuntasan penguasaan konsep dan keterampilan berpikir kritis. Berdasarkan hasil analisis data dapat disimpulkan bahwa perangkat pembelajaran IPA berdasarkan model Problem Based Learning untuk melatihkan penguasaan konsep dan keterampilan berpikir kritis siswa SD, telah valid, praktis dan efektif sehingga layak digunakan dalam kegiatan pembelajaran.
\end{abstract}

Kata Kunci: Model Problem Baseed Learning (PBL),Pemahaman Konsep, Keterampilan Berpikir Kritis.

\section{Abstract}

This study aims to train ability of understanding the concepts comprehension and critical thinking skills of fourth grade students of SDN Jambu Hilir Baluti 2 through use learning model Problem Based Learning in the matter of pollution and environmental ethics. This lesson is designed to enable students to find their own solutions through concrete actions. This type of research is an experimental study comparing students in two different classes be given treatment The study design using Counter Balanced Design. Subject of the study consisted of a control class and experimental class. The research data were collected through the instrument test the concept of multiple choice comprehension, and critical thinking in the form of an essay. Learning device consists of RPP, Activity Sheet Students, Test Mastery of Concepts and Skills Test Critical Thinking, then validated by experts and having been declared valid and appropriate, tested on grade IV SDN Jambu Hilir Baluti 2, in the first semester 2015/2016 academic year. The results showed that the validity of the learning device developed feasible, feasibility RPP performing well, increasing student-centered activities to students, student responses to the learning process gives a positive response, all students achieve mastery of concepts and critical thinking skills. Based on the results of data analysis can be concluded that the science teaching based on the model of Problem Based Learning to train mastery of concepts and critical thinking skills of elementary school students, have a valid, practical and effective so that used in learning activities.

Keywords: Model Problem Based Learning, Concept Comprehension, Critical Thinking Skills.

\section{PENDAHULUAN}

Keterampilan proses meliputi keterampilan mengamati, mengajukan hipotesis, menggunakan alat dan bahan secara baik dan benar dengan selalu mempertimbangkan keamanan dan keselamatan kerja, mengajukan pertanyaan, menggolongkan dan menafsirkan data, serta mengkomunikasikan hasil temuan secara lisan dan tertulis, menggali dan memilah informasi faktual yang relevan untuk menguji gagasangagasan atau memecahkan masalah sehari-hari.
Pada pemecahan masalah, siswa harus mengetahui aturan yang relevan dan didasarkan pada konsep-konsep yang diperolehnya (Dahar, 1996). Penguasaan konsep sangat diperlukan dan merupakan bagian utuh dalam proses pembelajaran harus menjadi salah satu tolak ukur keberhasilan kegiatan belajar mengajar karena siswa nantinya dihadapkan dengan permasalahan yang memerlukan pemecahan masalah dan solusi yang memerlukan kemampuan dalam menghubungkan penguasaan konsep dengan pemecahan masalah untuk melatih kempuan berpikir kritis siswa. 
Pengaruh Model Problem Based Learning (PBL) Terhadap Pemahaman Konsep Dan Keterampilan Berpikir Kritis Siswa Kelas IV SDN Jambu Hilir Baluti 2 pada Mata Pelajaran Ilmu Pengetahuan Alam

Syahroni Ejin

Berpikir kritis adalah kemampuan belajar yang harus diajarkan pada siswa karena kemampuan ini sangat diperlukan dalam kehidupan (Schaferman, 1991). Berpikir kritis siswa adalah salah satu kecakapan hidup yang perlu dilatihkan sejak sekolah dasar untuk memberikan bekal yang baik untuk kehidupan siswa. Hal tersebut juga yang perlu diketahui oleh guru pentingnya melatih keterampilan berpikir kritis siswa.

Hal tersebut sejalan dengan kurikulum KTSP (Depdiknas, 2006) bahwa IPA berhubungan dengan cara mencari tahu tentang alam secara sistematis, sehingga bukan hanya penguasaan kumpulan pengetahuan yang berupa fakta, konsep, atau prinsip saja tetapi juga merupakan suatu proses penemuan. Selain itu IPA juga meruapakan ilmu yang bersifat empirik dan membahas tentang fakta serta gejala alam.

Dari hasil pengamatan secara langsung pada saat pelaksanaan pembelajaran ditemukan beberapa permasalahan baik permasalahan yang berasal dari siswa maupun dari guru. Permasalahan dari siswa adalah dari siswa pasif, yakni kurang memperhatikan penjelasan guru, kurang berani untuk bertanya dan menjawab pertanyaan secara lisan, kurang konsentrasi pada saat pembelajaran IPA, dan belum mampu memecahkan permasalahan dengan baik.

Dari hasil observasi awal yang dilakukan pada siswa SDN Jambu Hilir Baluti 2 tahun pelajaran 2014/2015 pada mata pelajaran IPA, hanya 30\% yang mampu memahami konsep dan berpikir kritis. Dari hasil rekapitulasi nilai siswa di SDN Jambu Hilir Baluti 2 tahun 2014/2015 hasil belajar kognitif siswa pada mata pelajaran IPA juga rendah hanya $50 \%$ yang memenuhi nilai standar ketuntasan belajar.

Berdasarkan observasi peneliti di sekolah tersebut diperoleh bahwa gambaran keadaan siswa secara umum adalah: (1) siswa jarang mengajukan pertanyaan walaupun sudah diberikan kesempatan untuk bertanya,

(2) siswa tidak dapat memberikan penjelasan dan alasan mengenai jawaban yang dipilih, (3) siswa tidak dapat mengungkapkan secara tepat mengenai jawaban yang telah dipilih.

Hasil observasi kegiatan belajar mengajar di atas menunjukan bahwa tingkat keterampilan berpikir kritis yang dimiliki siswa masih rendah dan ini salah satunya dapat berdampak pada pencapaian kopetensi lulusan pembelajaran IPA, karena salah satu standar kelulusan (SKL) yang harus dicapai adalah menunjukan kemampuan berpikir kritis logis, kritis, kreatif dan inovatif.

Uraian di atas seharusnya guru harus mampu mengubah kebiasaan dan membuat terobosan baru dalam prose pembelajaran. Mengubah kebiasaan dengan siswa yang hanya memeroleh konsep dari guru dengan membimbing siswa dalam kelompok manupun secara individual untuk menguasai konsep secara mendasar. Salah satu terobosan tersebut adalah menggunakan model pembelajaran yang berkaitan dengan kemampuan pemahaman konsep dan kemampuan berpikir kritis adalah model pembelajaran problem basid learning (PBL). Didasarkan pada teori belajar konstruktivis. Model pembelajaran PBL merupakan salah satu contoh model pembelajaran terbaik untuk pembelajaran konstruktivis (Akcay, 2009).

Model pembelajaran PBL siswa dihadapkan pada masalah kehidupan yang nyata (kontekstual) dari lingkungan sehingga dapat meningkatkan kemampuan pemahaman konsep dan berpikir kritis siswa. Hal tersebut didukung oleh pendapat Ennis (1996) bahwa kemampuan berpikir kritis dapat ditingkatkan dengan melalui observasi atau pengamatan. Melalui kegiatan observasi, siswa dapat mengidentifikasi permasalahan lingkungan yang ada disekitarnya. Ketika siswa mengetahui permasalahan lingkungan yang dekat dengan lingkungan hidupnya, siswa diharapkan dapat berlatih untuk mengembangkan kemampuan berpikir kritis sehingga dapat mengetahui solusi yang tepat untuk permasalahan tersebut.

Problem Based Learning (PBL) mampu menjembatani perbedaan karakteristik siswa. Pembelajaran dengan PBL menjadikan konsep IPA yang abstrak disajikan secara nyata atau realistik, dengan begitu siswa benar-benar memahami konsep-konsep tentang "Pencemaran dan Etika Lingkungan" serta mampu berpikir kritis bagaimana memecahkan masalah yang terjadi pada lingkungan. Siswa diaktifkan melalui percobaan, pengamatan dan diskusi.

Hasil penelitian lain dari Sastrawati (2011) membuktikan bahwa pembelajaran model PBL mempunyai pengaruh yang signifikan terhadap perkembangan kemampuan siswa untuk berpikir kritis dibandingkan model pembelajaran konvensional. Beberapa hasil penelitian peneliti terdahulu, dapat disimpulkan bahwa model Problem Based Learning (PBL) berpengaruh terhadap kemampuan pemahaman konsep dan kemampuan berpikir kritis siswa. Hasil penelitian tersebut menunjukkan terdapat perbedaan yang cukup signifikan antara siswa yang mendapatkan pembelajaran Problem Based Learning (PBL) dengan pembelajaran konvensional dalam hal kemampuan berpikir kritis dan kemampuan pemahaman konsep.

Permasalahan kehidupan siswa dan lingkungan sekitar tersebut menuntutnya untuk berpikir kritis sehingga mendapatkan solusi yang tepat untuk menyelesaikannya. Hal ini menjadi penting karena tidak 
sedikit permasalahan lingkungan yang muncul akibat faktor manusia itu sendiri. Pentingnya berpikir kritis agar siswa mampu menguasai situasi-situasi dan permasalahan baru yang senantiasa muncul dalam permasalahan lingkungan, hal demikian dapat terwujud apabila dalam proses berpikir kritis siswa memiliki kesadaran untuk merancang, memantau dan menilai apa yang akan dipelajari.

Siswa yang memiliki kemampuan berpikir kritis mampu membuat pertimbangan yang cermat dalam mengambil keputusan untuk menentukan langkah apa yang harus dilakukan untuk menangani masalah pencemaran lingkungan yang ada disekitarnya. Pengambilan keputusan ini merupakan salah satu strategi untuk melatih pemahaman konsep. Berarti agar siswa mampu berpikir kritis mengenai masalah lingkungan diperlukan kemampuan pemahaman konsep dan berpikir kritis siswa.

Berdasarkan uraian latar belakang di atas maka rumusan masalah dalam penelitian ini adalah:

1. Bagaimanakah keterlaksanaan pembelajaran dengan model pembelajaran PBL pada mata pelajaran Ilmu Pengetahuan Alam? 2. Bagaimana perbedaan pemahaman konsep siswa pada kelas PBL dibandingkan kelas Konvensional pada mata pelajaran Ilmu Pengetahuan Alam? 3.Bagaimana perbedaan kemampuan berpikir kritis siswa pada kelas PBL dibandingkan kelas konvensional pada mata pelajaran Ilmu Pengetahuan Alam?

\section{METODE}

Jenis penelitian ini adalah quasi experimen yaitu perlakuan diberikan pada variabel bebas untuk menentukan pengaruhnya pada variabel terikat, tetapi variabel-variabel yang berpengaruh tidak dapat dikontrol dengan ketat (Tuckman, 1978).

Penelitian diadakan di SDN Jambu Hilir Baluti 2 Kabupaten Hulu Sungai Selatan, Kalimantan Selatan pada semester ganjil tahun pelajaran 2015/2016.

Populasi penelitian ini adalah siswa kelas IV SD Negeri Jambu Hilir Baluti 2, Kabupaten Hulu Sungai Selatan Tahun pelajaran 2015/ 2016, yang terdiri dari dua kelas paralel yaitu kelas IVa dan IVb. Sampel yang digunakan untuk Uji Coba II adalah 20 siswa dari kelas IVa dan 20 siswa kelas IVb, sedangkan metode pengambilan sampel adalah metode random (probability sampling). Menurut Sugiyono (2010) metode random adalah metode dimana pemilihan sampel tidak dilakukan secara subyektif. Sampel yang terpilih tidak didasarkan pada keinginan peneliti, sehingga setiap anggota sampel memiliki peluang yang sama untuk terpilih sebagai sampel.
Rancangan penelitian yang digunakan adalah counterbalanced design. Menurut Fraenkel, J. R. and Wallen, N. E. (2003) kelas pada kelompok penelitian dipilih secara random dan setiap kelompok diberi perlakuan secara bergantian setiap pertemuan. Tes akhir (posttest) diberikan baik pada kelas kontrol maupun kelas eksperimen setiap selesai perlakuan.

Teknik Pengumpulan data dalam penelitian ini menggunakan teknik sebagai berikut. 1) Dokumentasi, yaitu untuk memperoleh informasi yang berkaitan dengan nilai ulangan harian siswa di kelas IV. 2) Pengamatan, untuk mengumpulkan data penelitian dengan menggunakan lembar-lembar pengamatan yang telah diadaptasi seperti pengamatan keterlaksanaan pembelajaran. Pengamatan dilakukan oleh dua guru mata pelajaran di sekolah tempat penelitian dilaksanakan. Pada saat peneliti melaksanakan pembelajaran maka dua orang guru di sekolah yang bersangkutan bertindak sebagai pengamat. 3) Pemberian Tes pemahaman konsep dan berpikir kritis siswa, untuk mengetahui skor siswa dalam kemampuan pemahaman konsep dan kemampuan berpikir kritis. Tes pemahaman konsep terdiri dari lima soal pilihan ganda dan kemampuan berpikir kritis dalam bentuk lima soal esai. Tes dilaksanakan setiap selesai perlakuan model pembelajaran konvensional dan PBL.

Validasi perangkat bertujuan untuk memeroleh kelayakan dari para validator (ahli yang berkompeten bagi peningkatan bahan pembelajaran) adalah dengan melakukan kegiatan validasi pada tahap perencanaan perangkat. Hasil penilaian dari para validator selanjutnya ditindak lanjuti oleh peneliti sesuai dengan saran dan arahan dari validator. Instrument yang di validasi berupa instrument validasi silabus, RPP, media pembelajaran, LKS, lembar penilaian tes pemahaman konsep dan berpikir kritis.

Analisis data validasi yang meliputi validasi perangkat dilakukan dengan statistik deskritif kualitatif, yaitu dengan merata-rata skor masing-masing komponen yang diperoleh dari validator. Hasil skor rata-rata dideskripsikan sebagai berikut:

Tabel 1 Analisis Data Validasi Perangkat

\begin{tabular}{|l|l|lr|}
\hline $\begin{array}{l}1,0 \leq \mathrm{SV} \\
\leq 1,5\end{array}$ & $\begin{array}{l}\text { Tidak } \\
\text { layak }\end{array}$ & $\begin{array}{l}\text { Belum dapat digunakan dan } \\
\text { masih } \\
\text { konsultasi }\end{array}$ \\
\hline $\begin{array}{l}1,5 \leq \mathrm{SV} \\
\leq 2,5\end{array}$ & $\begin{array}{l}\text { Kurang } \\
\text { layak }\end{array}$ & $\begin{array}{l}\text { Dapat digunakan } \\
\text { banyak revisi }\end{array}$ & dengan \\
\hline $\begin{array}{l}2,5 \leq \mathrm{SV} \\
\leq 3,5\end{array}$ & Layak & $\begin{array}{l}\text { Dapat digunakan } \\
\text { sedikit revisi }\end{array}$ & dengan \\
\hline $\begin{array}{l}3,5 \leq \\
\mathrm{SV} \leq 4,0\end{array}$ & $\begin{array}{l}\text { Sangat } \\
\text { layak }\end{array}$ & $\begin{array}{l}\text { Dapat digunakan } \\
\text { revisi }\end{array}$ & tanpa \\
\hline
\end{tabular}

(diadaptasi dari Ratunaman \& Laurens, 2006). 
Pengaruh Model Problem Based Learning (PBL) Terhadap Pemahaman Konsep Dan Keterampilan Berpikir Kritis Siswa Kelas IV SDN Jambu Hilir Baluti 2 pada Mata Pelajaran Ilmu Pengetahuan Alam

Syahroni Ejin

Pada uji validitas butir soal, skor setiap butir soal dikorelasikan dengan skor total agar diketahui dengan pasti butir soal yang tidak memenuhi syarat. Perhitungan ini menggunakan rumus korelasi Pearson Product Moment sebagai berikut.

$r_{x y}=\frac{N \sum X Y-\left(\sum X\right)\left(\sum Y\right)}{\sqrt{\left\{N \sum X^{2}-\left(\sum X\right)^{2}\right\}\left\{N \sum Y^{2}-\left(\sum Y\right)^{2}\right\}}}$

Keterangan:

$r_{x y}=$ koefisien korelasi product moment

$\mathrm{N}$ = banyaknya subyek

$\sum \mathrm{X}=$ jumlah skor total

$\sum \mathrm{X}^{2}=$ jumlah kuadrat skor total

$\sum \mathrm{Y}=$ jumlah skor total

$\sum \mathrm{Y}^{2}=$ jumlah kuadrat skor total

Reliabilitas instrumen soal uraian pada penelitian ini menggunakan rumus Alpha sebagai berkut.

$$
r_{11}=\left[\frac{k}{(k-1)}\right]\left[1-\frac{\sum b_{b}^{2}}{b_{t^{2}}}\right]
$$

Keterangan :

$$
\begin{aligned}
& \mathrm{k}=\text { banyaknya butir soal } \\
& \sum \delta_{b^{2}}=\text { jumlah varians butir } \\
& \delta_{t^{2}}=\text { varians total }
\end{aligned}
$$

Pengujian validitas adalah analisis yang dilakukan untuk mengetahui tingkat keandalan dan kesahihan butir soal yang digunakan dengan kata lain uji validitas digunakan untuk mengetahui apakah butir sola yang digunakan valid atau dapat mengukur atau apa yang harus diukur adapun validitas instrumen pada materi pencemaran tanah dapat dilihat bahwa semua nilai $r$ hitung > $\mathrm{r}$ tabel, hasil $\mathrm{r}$ hitung didapat dari output SPSS pada kolom corrected item-total correlation, nilai $r$ tabel $(0,312)$ dapat dilihat pada lampiran tabel dengan $\mathrm{df}=\mathrm{n}-$ $2=40-2=38$, sehingga seluruh butir soal pada instrumen pemahaman konsep pencemaran tanah valid. Pengujian validitas instrumen pada materi pencemaran air dapat dilihat bahwa semua nilai $\mathrm{r}$ hitung $>\mathrm{r}$ tabel, hasil $r$ hitung didapat dari output SPSS pada kolom corrected item-total correlation bahwa nilai $\mathrm{r}$ tabel $(0,312)$ dapat dilihat pada lampiran tabel dengan $\mathrm{df}=\mathrm{n}-$ $2=40-2=38$, dengan demikian seluruh butir soal pada instrumen pemahaman konsep pencemaran air valid. Pengujian validitas instrumen pada materi pencemaran udara dapat dilihat bahwa semua nilai $r$ hitung $>r$ tabel, hasil $r$ hitung didapat dari output SPSS pada kolom corrected item-total correlation bahwa nilai $\mathrm{r}$ tabel $(0,312)$ dapat dilihat pada lampiran tabel dengan $\mathrm{df}=\mathrm{n}-$ $2=40-2=38$, sehingga seluruh butir soal pada instrumen pemahaman konsep pencemaran udara valid. Pengujian validitas instrumen pada materi pencemaran udara dapat dilihat bahwa semua nilai $\mathrm{r}$ hitung $>\mathrm{r}$ tabel, hasil $\mathrm{r}$ hitung didapat dari output SPSS pada kolom corrected item-total correlation bahwa nilai $\mathrm{r}$ tabel $(0,312)$ dapat dilihat pada lampiran tabel dengan $\mathrm{df}=\mathrm{n}-$ $2=40-2=38$, sehingga seluruh butir soal pada instrumen pemahaman konsep pencemaran dan etika lingkungan valid.

Untuk menganalisis hasil penelitian keterlaksanaan pembelajaran digunakan ketentuan sebagai berikut. Tabel

Tabel 2 Kriteria Keterlaksanaan Pembelajaran

\begin{tabular}{|c|c|c|}
\hline No & Skor & Kriteria \\
\hline 1 & $1,00-1,99$ & Kurang baik (KB) \\
\hline 2 & $2,00-2,99$ & Cukup baik (CB) \\
\hline 3 & $3,00-3,49$ & Baik (B) \\
\hline 4 & $3,50-4,00$ & Sangat baik (SB) \\
\hline
\end{tabular}

Deskripsi umum kemampuan pemahaman konsep dan kemampuan berpikir kritis selanjutnya adalah memberikan predikat secara kualitatif untuk setiap rentangan nilai tertentu. Pedoman pengkategorian nilai tersebut diadaptasi dari Gronlund (2003).

Tabel 3 Pedoman Pengkategorian Nilai

\begin{tabular}{|c|c|c|}
\hline \multicolumn{3}{|c|}{$\begin{array}{c}\text { Kemampuan Pemahaman konsep dan } \\
\text { kemampuan berpikir siswa }\end{array}$} \\
\hline $\begin{array}{c}\text { Rentangan } \\
\text { persentase } \\
\text { Skor jawaban }(\%)\end{array}$ & $\begin{array}{c}\text { Rentangan } \\
\text { Nilai }\end{array}$ & Kategori \\
\hline $95-100$ & $95-100$ & Memuaskan \\
\hline $85-94$ & $85-94$ & Sangat baik \\
\hline $75-84$ & $75-84$ & Baik \\
\hline $65-74$ & $65-74$ & Sedang \\
\hline$<65$ & $<65$ & Kurang \\
\hline
\end{tabular}

(Diadaptasi dari Gronlund, 2003).

Hipotesis penelitian ditetapkan sebagai berikut. a) $\mathrm{H}_{\mathrm{o}}: \mu_{1}=\mu_{2}$ : tidak terdapat perbedaan kemampuan pemahaman konsep antara kelas PBL dan kelas konvensional. b) $\mathrm{H}_{\mathrm{a}}: \mu_{1} \neq \mu_{2}$ : terdapat perbedaan kemampuan pemahaman konsep antara kelas PBL dibandingkan kelas konvensional. c) $\mathrm{H}_{\mathrm{o}}: \mu_{1}=\mu_{2}$ : tidak terdapat perbedaan kemampuan berpikir kritis antara kelas PBL dan kelas konvensional. $\mathrm{H}_{\mathrm{a}}: \mu_{1} \neq \mu_{2}$ : terdapat perbedaan kemampuan berpikir kritis antara sampel kelas PBL daripada sampel kelas konvensional.

Tingkat signifikansi dalam penelitian ini ditetapkan sebesar 0,05 dengan pengujian dua sisi. Dasar pengambilan keputusan dengan menetapkan kriteria terima $\mathrm{H}_{\mathrm{o}}$ jika probabilitas $>0,05$ dan tolak $\mathrm{H}_{\mathrm{o}}$ jika probabilitas $<0,05$. 


\section{HASIL DAN PEMBAHASAN}

1. Tahap Pelaksanaan

Hasil pengamatan keterlaksanaan pembelajaran model PBL diarahkan pada lima kegiatan utama, yaitu: Pendahuluan, Kegiatan Inti, Penutup, Pengelolaan Waktu dan KBM serta Suasana Kelas. Untuk kegiatan Pendahuluan memunyai rentang nilai dalam kategori baik sampi sangat baik yaitu 3,2-3,6. Koefisien reliabilitas yang diperoleh dengan rentang nilai 90-93. Untuk Kegiatan Inti memunyai rentang nilai dalam kategori baik sampai sangat baik yaitu 3,2-3,8. Koefisien reliabilitas yang diperoleh dengan rentang nilai $90-98$. Untuk Kegiatan Penutup memunyai rentang nilai dalam kategori baik sampai sangat baik yaitu 3,3-3,5. Koefisien reliabilitas yang diperoleh dengan rentang nilai 91-94. Untuk Pengelolaan Waktu dan KBM memunyai rentang nilai dalam kategori baik sampai sangat baik yaitu 3,3-3,7. Koefisien reliabilitas yang diperoleh dengan rentang nilai 91-97. Untuk penilaian Suasana Kelas memunyai nilai dalam kategori baik sampai sangat baik yaitu . 3,3-3,5. Koefisien reliabilitas yang diperoleh dengan rentang nilai 91-94. Pembelajaran secara keseluruhan dapat dikategonkan baik sampai sangat baik, Gambaran ini menunjukkan pembelajaran dilaksanakan dengan baik dan sesuai dengan rencana pembelajaran yang dikembangkan. Guru mampu mengelola waktu dengan baik.

Hasil Uji Tes Pemahaman Konsep pada Materi Pencemaran dan Etika Lingkungan

1. Uji Normalitas

\begin{tabular}{|c|c|c|}
\hline \multicolumn{3}{|c|}{ One-Sample Kolmogorov-Smirnov Test } \\
\hline & & Nilai \\
\hline $\bar{N}$ & & 40 \\
\hline \multirow[t]{2}{*}{ Normal Parameters $a, b$} & Mean & 80,63 \\
\hline & Std. Deviation & 7,941 \\
\hline Most Extreme & Absolute & , 161 \\
\hline \multirow[t]{2}{*}{ Differences } & Positive & , 161 \\
\hline & Negative &,- 139 \\
\hline Kolmogorov-Smirnov $Z$ & & 1,016 \\
\hline Asy mp. Sig. (2-tailed) & & ,253 \\
\hline
\end{tabular}

Pada tabel pengujian normalitas dengan kolmogorovSmirnov di atas menunjukkan bahwa nilai signifikansi atau probabilitas adalah 0,253>0,05, sehingga dapat disimpulkan bahwa data berdistribusi normal.

2. Uji Homogenitas

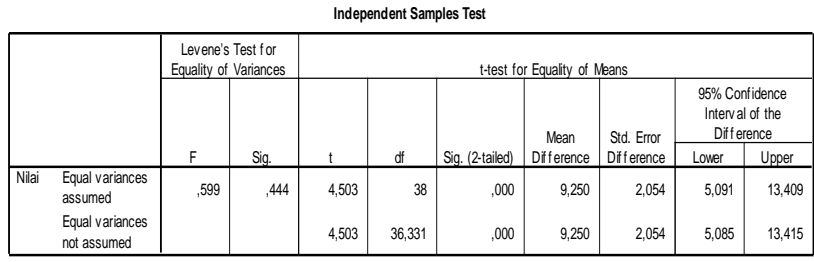

Pada pengujian homogenitas varian dengan menggunakan Levene's Test of Equality of error for Variances menunjukkan bahwa nilai signifikansi atau probabilitas adalah $0,444>0,05$, sehingga dapat disimpulkan bahwa varian data homogen. Berdasarkan hasil pengujian normalitas dan homogenitas, maka dilakukan uji parametrik untuk dua data yang tidak berhubungan yaitu uji Independent Sample T-test.

3. Uji Hipotesis

Berdasarkan hasil analisis Independent Sample Ttest diperoleh nilai probabilitas (Asymp.Sig (2-tailed)) = $0,000<0,05$. Hal ini menunjukkan Ho ditolak dan H1 diterima, jadi dapat disimpulkan bahwa kemampuan pemahaman konsep pada materi pencemaran antara kelas PBL dan kelas konvensional berbeda.

\begin{tabular}{|c|c|c|c|c|c|}
\hline \multicolumn{6}{|c|}{ Group Statistics } \\
\hline & Metode Pembelajaran & $\mathrm{N}$ & Mean & Std. Deviation & $\begin{array}{c}\text { Std. Error } \\
\text { Mean }\end{array}$ \\
\hline \multirow[t]{2}{*}{ Nilai } & PBL & 20 & 85,25 & 7,159 & 1,601 \\
\hline & Konv ensional & 20 & 76,00 & 5,758 & 1,288 \\
\hline
\end{tabular}

Berdasarkan tabel di atas rata-rata kemampuan pemahaman konsep pada kelas PBL 85,25 lebih tinggi dibandingkan rata-rata kelas konvesional yaitu sebesar 76,00 .

Hasil Uji Tes Kemampuan Berpikir Kritis pada Materi Pencemaran dan Etika Lingkungan

1. Uji Normalitas

\begin{tabular}{|c|c|c|}
\hline \multicolumn{3}{|c|}{ One-Sample Kolmogorov-Smirnov Test } \\
\hline & & Nilai \\
\hline \multicolumn{2}{|l|}{$\bar{N}$} & 40 \\
\hline \multirow[t]{2}{*}{ Normal Parameters $\mathrm{a}, \mathrm{b}$} & Mean & 75,25 \\
\hline & Std. Deviation & 10,436 \\
\hline \multirow{3}{*}{$\begin{array}{l}\text { Most Extreme } \\
\text { Differences }\end{array}$} & Absolute & 125 \\
\hline & Positive & 103 \\
\hline & Negative & -125 \\
\hline \multicolumn{2}{|l|}{ Kolmogorov-Smirnov Z } & ,790 \\
\hline \multicolumn{2}{|l|}{ Asy mp. Sig. (2-tailed) } &, 560 \\
\hline
\end{tabular}

Pada tabel pengujian normalitas dengan kolmogorov-Smirnov di atas menunjukkan bahwa nilai signifikansi atau probabilitas adalah 0,560>0,05, sehingga dapat disimpulkan bahwa data berdistribusi normal.

2. Uji Homogenitas

Independent Samples Test

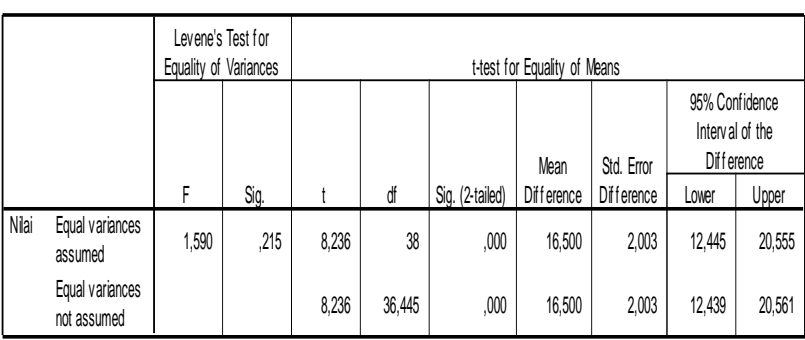


Pengaruh Model Problem Based Learning (PBL) Terhadap Pemahaman Konsep Dan Keterampilan Berpikir Kritis Siswa Kelas IV SDN Jambu Hilir Baluti 2 pada Mata Pelajaran Ilmu Pengetahuan Alam

Syahroni Ejin

Pada pengujian homogenitas varian dengan menggunakan Levene's Test of Equality of error for Variances menunjukkan bahwa nilai signifikansi atau probabilitas adalah $0,215>0,05$, sehingga dapat disimpulkan bahwa varian data homogen. Berdasarkan hasil pengujian normalitas dan homogenitas, maka dilakukan uji parametrik untuk dua data yang tidak berhubungan yaitu uji Independent Sample T-test .

3. Uji Hipotesis

Berdasarkan hasil analisis Independent Sample Ttest diperoleh nilai probabilitas (Asymp.Sig (2-tailed)) $=$ $0,000<0,05$. Hal ini menunjukkan Ho ditolak dan H1 diterima, jadi dapat disimpulkan bahwa kemampuan berpikir kritis pada materi pencemaran antara kelas PBL dan kelas konvensional berbeda.

\begin{tabular}{|c|c|c|c|c|c|}
\hline \multicolumn{6}{|c|}{ Group Statistics } \\
\hline & Metode Pembelajaran & $\mathrm{N}$ & Mean & Std. Deviation & $\begin{array}{c}\text { Std. Error } \\
\text { Mean }\end{array}$ \\
\hline \multirow[t]{2}{*}{ Nilai } & PBL & 20 & 83,50 & 5,643 & 1,262 \\
\hline & Konv ensional & 20 & 67,00 & 6,959 & 1,556 \\
\hline
\end{tabular}

Berdasarkan tabel di atas rata-rata kemampuan pemahaman konsep pada kelas PBL 83,50 lebih tinggi dibandingkan rata-rata kelas konvesional yaitu sebesar 67,00 .

Hasil pengamatan keterlaksanaan rencana pembelajaran pada pertemuan 1,2,3 dan 4 menunjukan kategori baik sampai dengan sangat baik. Hal ini menunjukkan bahwa rencana pelaksanaan pembelajran (RPP) Problem Based Learning (PBL), dapat digunakan pada proses pembelajaran untuk melatihkan kemampuan pemahaman konsep dan kemampuan berpikir kritis pada siswa kelas IV SDN Jambu Hilir Baluti 2.

Beberapa faktor pendukung ketercapaian persentase keterlaksanaan pembelajaran PBL adalah: (1) pembelajaran PBL telah direncanakan dengan baik dan sistematis oleh guru. Dapat dilihat dari ketersediannya perangkat pembelajaran yang memiliki kualitas yang semakin baik. Hal ini karena telah ditelaah ulang dan dilaksanakan perbaikan pada beberapa bagian setelah divalidasi dan diberi masukan oleh validator 1 dan 2 . Baik pada rancangan pembelajaran (RPP) ataupun pada instrumen soal. Instrumen soal tersebut telah diuji coba I, serta ketersediaan alat dan bahan yang dibutuhkan selama kegiatan pembelajaran PBL. (2) LKS yang digunakan dalam proses pembelajaran juga dinyatakan layak untuk digunakan pada pembelajaran PBL oleh validator 1 dan 2. LKS dirancang untuk melatih pemahaman konsep dan berpikir kritis siswa. Kemampuan tersebut dilatih melalui kegiatan penyelidikan mandiri suatu permasalahan otentik dipadu dengan serangkaian pertanyaan dalam LKS.
Pengujian normalitas digunakan untuk mengetahui kenormalan data, adapun Pengujian normalitas dengan perhitungan statistik kolmogorov-Smirnov menunjukkan bahwa nilai signifikansi atau probabilitas adalah 0,253 > 0,05, sehingga dapat disimpulkan bahwa data berdistribusi normal. Pengujian homogenitas digunakan untuk menguji apakah varian data homogeny/identik, asumsi yang harus dipenuhi dalam pengujian independent sampel $\mathrm{T}$ tes adalah data normal dan variannya homogen, adapun pengujian homogenitas varian dengan menggunakan Levene's Test of Equality of error for Variances menunjukkan bahwa nilai signifikansi atau probabilitas adalah 0,444>0,05, jadi dapat disimpulkan bahwa varian data homogen. Berdasarkan hasil pengujian normalitas dan homogenitas, maka dilakukan uji parametrik untuk dua data yang tidak berhubungan yaitu uji Independent Sample T-test. Uji hipotesis digunakan untuk menguji hipotesis dalam hal ini menguji perbedaan rata rata, adapun uji hipotesis berdasarkan hasil analisis Independent Sample T-test diperoleh nilai probabilitas (Asymp.Sig (2-tailed)) $=0,000<0,05$. Hal ini menunjukkan Ho ditolak dan $\mathrm{H} 1$ diterima. Dapat disimpulkan bahwa kemampuan pemahaman konsep pada materi pencemaran dan etika lingkungan antara kelas Problem Based Learning (PBL) dan kelas konvensional berbeda. Berdasarkan tabel rata-rata kemampuan pemahaman konsep pada kelas Problem Based Learning (PBL) 85,25 lebih tinggi dibandingkan rata-rata kelas konvesional yaitu sebesar 76,00.

Pengaruh kelas yang menggunakan model Problem Based Learning (PBL) dibandingkan dengan kelas yang menggunakan model Konvensional terhadap kemampuan berpikir kritis siswa. Pengujian validitas adalah analisis yang dilakukan untuk mengetahui tingkat keandalan dan kesahihan butir soal yang digunakan dengan kata lain uji validitas digunakan untuk mengetahui apakah butir sola yang digunakan valid atau dapat mengukur atau apa yang harus diukur pengujian validitas instrumen pada materi pencemaran tanah dapat dilihat bahwa semua nilai $r$ hitung $>r$ tabel. Hasil $r$ hitung didapat dari output SPSS pada kolom corrected item-total correlation bahwa nilai $\mathrm{r}$ tabel $(0,312)$ dapat dilihat pada lampiran tabel dengan df $=\mathrm{n}-2=40-2=$ 38. Jadi seluruh butir soal pada instrumen kemampuan berpikir kritis materi pencemaran tanah valid. Pengujian validitas instrumen pada materi pencemaran air dapat dilihat bahwa semua nilai $r$ hitung $>r$ tabel, hasil $r$ hitung didapat dari output SPSS pada kolom corrected itemtotal correlation bahwa nilai $\mathrm{r}$ tabel $(0,312)$ dapat dilihat pada lampiran tabel dengan $\mathrm{df}=\mathrm{n}-2=40-2=38$, dengan nilai tersebut dapat dinyatakan bahwa seluruh butir soal pada instrumen kemampuan berpikir kritis pada 
materi pencemaran air valid. Pengujian validitas instrumen pada materi pencemaran udara dapat dilihat bahwa semua nilai $\mathrm{r}$ hitung $>\mathrm{r}$ tabel, hasil $\mathrm{r}$ hitung didapat dari output SPSS pada kolom corrected itemtotal correlation bahwa nilai $r$ tabel $(0,312)$ dapat dilihat pada lampiran tabel dengan $\mathrm{df}=\mathrm{n}-2=40-2=38$. sehingga seluruh butir soal pada instrumen kemampuan berpikir kritis pencemaran udara valid. Pengujian validitas instrumen pada materi pencemaran dan etika lingkungan dapat dilihat bahwa semua nilai $r$ hitung $>r$ tabel, hasil $r$ hitung didapat dari output SPSS pada kolom corrected item-total correlation bahwa nilai $\mathrm{r}$ tabel $(0,312)$ dapat dilihat pada lampiran tabel dengan $\mathrm{df}=\mathrm{n}-$ $2=40-2=38$. Sehingga seluruh butir soal pada instrumen kemampuan berpikir kritis pada materi pencemaran dan etika lingkungan valid.

Dapat disimpulkan bahwa kemampuan berpikir kritis pada materi pencemaran dan etika lingkungan antara kelas Problem Based Learning (PBL) dan kelas konvensional berbeda. Berdasarkan tabel rata-rata kemampuan pemahaman konsep pada kelas Problem Based Learning 83,50 lebih tinggi dibandingkan rata-rata kelas konvesional yaitu sebesar 67,00.

\section{PENUTUP}

Berdasarkan temuan-temuan penelitian pada uji coba II, maka dapat di simpulkan bahwa model Problem Based Learning (PBL) pada pokok bahasan Pencemaran dan Etika Lingkungan memberi pengaruh serta dapat meningkatkan pemahaman konsep dan keterampilan berpkir kritis siswa kelas IV SDN Jambu Hilir Baluti 2, karena: 1) Keterlaksanaan pembelajaran IPA dengan menggunakan perangkat pembelajaran berorientasi pada model Problem Based Learning (PBL) berada pada kategori baik. 2) Kemampuan pemahaman konsep siswa yang mendapatkan perlakuan dengan model pembelajaran Problem Based Learning (PBL) secara signifikan lebih baik dan lebih tinggi dibandingkan kelas Konvensional. 3) Kemampuan berpikir kritis siswa yang mendapatkan perlakuan dengan model pembelajaran Problem Based Learning (PBL) secara signifikan lebih baik dan lebih tinggi dibandingkan kelas konvensional.

Berdasarkan hasil penelitian, peneliti dapat memberikan saran sebagai berikut. 1) Model pembelajaran PBL dapat digunakan untuk meningkatkan kemampuan pemahaman konsep dan berpikir kritis siswa pada materi Pencemaran dan Etika Lingkungan di sekolah dasar jika masalah tersebut sama dengan masalah yang dialami oleh siswa pada penelitian ini. 2) Penggunaan model PBL adalah model yang tepat dalam mengajarkan materi Pencemaran dan Etika Lingkungan di sekolah dasar, hal ini karena telah terbukti mampu meningkatkan pemahaman konsep dan kemampuan berpikir kritis siswa.

\section{DAFTAR PUSTAKA}

Akcay, B. 2009. Problem Based Learning in Science Education. Journal of Turkish Science Education. Volume 6. Issue 1. April 2009. Diakses melalui http://www.tused.org pada tanggal 10 November 2014.

Dahar, R.W (1998). Teori-teori Belajar dan Pembelajaran. Jakarta. Erlangga.

Ennis, R. 1996. Critical Thinking: What is it? Proceeding of the Forty-Eight. Annual Meeting of the Philosophy of Education Society: Denver.

Scharferman, S.D. 1999. An Introduction to critical thinking. Diakses melalui http://freeinquiry.com/critical-thinking.html pada tanggal 9 januari 2015.
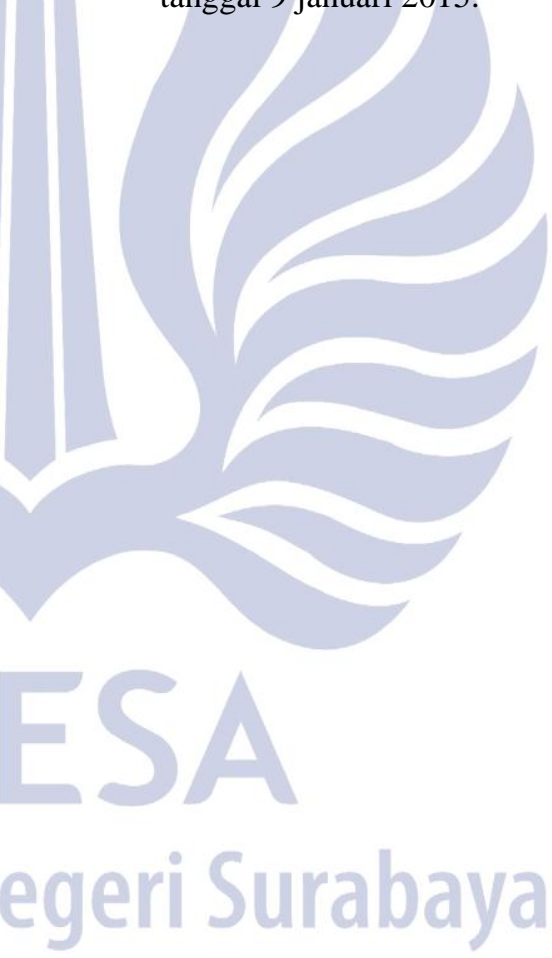